\title{
LIFE IMPRISONMENT AND HUMAN DIGNITY *
}

\section{Prisión perpetua y dignidad humana}

Silvio Cuneo**

Recepción: 20 de febrero de 2020. Aceptación: 3 de enero de 2021. DOI: http:/ / dx.doi.org/10.21017/Rev.Repub.2021.v30.a103

\begin{abstract}
Recognition of human dignity and respect for fundamental human rights cannot be restricted to a single category of human beings. The idea that anyone could be considered non-persona, to whom an "Enemy criminal law" may be applied, is incompatible with an ultima ratio liberal notion of criminal law.

The humanisation of criminal law is manifested in the growing number of contemporary societies that have abolished or limited the death penalty. Nevertheless, life or long-term imprisonment sentences still prevail, and are on the rise, despite lacking theoretical or philosophical justification in the laws that prescribe them.

In this article we will attempt to answer various questions regarding a possible justification for life imprisonment. Different theories will be examined regarding the goals of sentencing in order to determine, on discussing each theory, whether it is possible to justify life imprisonment or other long-term incarceration.
\end{abstract}

Keywords: life sentence- general prevention- special prevention- retributionpsychosocial development stages.

\section{RESUMEN}

El reconocimiento de la dignidad humana y el respeto por los derechos fundamentales no puede restringirse a una categoría de seres humanos. La posibilidad de concebir no-personas a las que es dable aplicar un Derecho penal de enemigos es incompatible con una concepción liberal, de ultima ratio, del Derecho penal.

* This article is part of the result of a research named «Estudio crítico de las causas del aumento del encarcelamiento en Chile desde el retorno de la democracia», CIP 2018003, developed within the Departamento de Derecho Público of the Universidad Central de Chile.

** Dr. in Law at the Universitat Pompeu Fabra and Universitá degli Studi di Trento. Master in Law at the Universitat Pompeu Fabra. Professor of Criminal Law at the Universidad Central de Chile. 
La humanización del Derecho penal se manifiesta en que muchas sociedades contemporáneas han ido suprimiendo y limitando la pena de muerte. Sin embargo, las penas perpetuas o extensas se mantienen y aumentan sin una justificación teórica o filosófico-jurídica de las mismas por parte de las leyes que las contemplan.

En este artículo intentaremos responder diversas interrogantes sobre las posibles justificaciones de la prisión perpetua, analizando las distintas teorías sobre el fin de la pena y viendo, con cada teoría, si es posible justificar la prisión perpetua u otras penas privativas de libertad de larga duración.

Palabras clave: prisión perpetua, prevención general, prevención especial, retribución, etapas del desarrollo psicosocial.

\section{INTRODUCTION}

This article develops a comprehensive argumentation of the fundamentals of punishment in a democratic state governed by the rule of law. As an introduction, we argue that neither capital punishment nor torture are compatible with respect for human dignity, and for the same reason, neither life imprisonment (which is torture and the death penalty) can be imposed without violating the dignity of the condemned person.

After questioning ourselves about the compatibility of theories regarding life imprisonment's goals, with life imprisonment, we will reach the conclusion that some relative theories provide justification based on facts substantiating the achievement of the very same desired ends. Absolute theories, on the other hand, are not compatible with life imprisonment. This is mainly due to two reasons: absolute theories perceive criminals as responsible for their own actions and therefore, they should be treated as such when judged, convicted and during the entire duration of their sentence, resulting in incompatible penalties dehumanising offenders. On the other hand, the retribution at the actual moment of sanctioning concentrates on the $I$, on the subject's identity, which changes over the course of time, inevitably meaning that after a certain period of time, an individual may no longer be blamed for a crime committed much earlier in their life.

Before embarking on a discussion of the matter in hand, it is worth recalling that, if the study of criminal law fulfils any important function, this can be none other than limiting punitive power, or at least an exposure of the mechanism of how it operates. Only by fulfilling its function of containment is it then possible to talk about criminal rather than punitive power or, in other words, criminal law becomes humanised when it limits punitive power and 
when the humanising of penal law is translated into the idea of citizens and not subordinates, whom it protects from the clutches of punitive power.

In this respect, this argument should be consistent erga onmes, and should be careful not to leave the door open to punitive power (which must always be limited) even in the case of tyrants or their collaborators. Otherwise, this door will remain open and will end up concentrating on and persecuting, as is usually the case, the most deprived members of society. This line of argument is the one followed - and taken to its extreme - by criminal abolitionism and it is no mere coincidence that one of its greatest exponents, Louk Hulsman, experienced at first hand the brutality of punitive power in a Nazi extermination camp.

Our proposal, less radical, distances itself from the idea of abolitionism for two main reasons: Firstly, because, at least in the case of crimes against humanity, we reject on the grounds of justice, any argument justifying impunity. However, as our argument is based on the criteria of justice, we also refute any cruel and inhuman punishment given that cruelty and inhumanity do not correspond to the very idea of justice. It is obvious, although worth reiterating, that with regards to liberal and humane criminal legislation, inhumane punishment cannot be applied, even when dealing with cruel and inhumane criminals themselves. In other words, justice, as the basis of punishment, does indeed demand those responsible to be sentenced (as opposed to impunity), but is also subject to limits compatible with the recognition of human dignity. The second reason has a realistic connotation, and it is best expressed in Rivacoba's words:

"While always bearing in mind the noble impulses which support all abolitionist actions and aspirations, it can be remembered in relation to any of them, and hence in relation to the abolitionist movement of our time [...] that, unless there is a transmutation in human nature and, consequently, in social demands and institutions, it is not, as in Stammler's well-known theory, the polar star for navigators, a port to reach and disembark, but a shining idea that acts as a guide and towards which to relentlessly head, a regulating principle, that is, a module that measures the degree of perfection, that is to say, of benignity, of the different punitive ordinances. On the other hand, maintaining that it is possible to achieve such a principle and strive to conquer it or reach it in our times may distract attention and efforts from the most urgent and feasible tasks; among those understanding in depth and rationally applying the current Law, undertaking or continuing a serious and consistent process of decriminalization or advancing towards the path of humanisation. Or in other words: that what is desirable does not prevent us or take away what is possible; that the maximalist flight to the 
absolute does not discourage us from a truly minimal, acceptable, dignified criminal law" (Rivacoba, 1993, p. XIII).

\section{QUESTIONS ABOUT LIFE IMPRISONMENT}

Life imprisonment and sentences that deprive liberty for an extensive time are questionable both because of the impact they have on the convicts ${ }^{1}$ and the high cost involved in keeping inmates behind bars in today's societies. In this respect we raise several questions that hopefully may shed light on in order to obtain a better understanding:

Can a penalty annulling prisoners have a place in a democratic society? Is life imprisonment a residue of barbaric societies? Are States that consider this sanction less democratic? Can life imprisonment be justified in the light of some theory about the goals of the sentence? Does life imprisonment satisfy the utilitarian requirements of general and special prevention? Can it be justified from a retributionist standpoint? Is it compatible with respect for human dignity?

There are no empirical studies in place that demonstrate that prisons can reduce crimes; on the contrary, it has been shown that incarceration either leaves crime figures unaltered or indeed increases them. Is life imprisonment compatible with the idea of re-education? On the other hand, if we cannot sentence anyone to life imprisonment, what do we do with those criminals who cannot be reintegrated? Is the penalty different from the security measure in the penitentiary reality? Furthermore, if re-education theories of have failed and prison has even been shown to be criminogenic, to encourage recidivism and generate a social stigma by labelling the offender ${ }^{2}$, will these empirical studies influence the way we should justify sentences?

\section{COMPATIBILITY OF LIFE IMPRISONMENT AND SENTENCE GOALS THEORIES}

Next, we will attempt to see whether life imprisonment can be justified according to the different theories on sentencing. We will start by analysing

1 On the effects of long prison sentences, field studies date back to the forties of the last century. On this subject: Clemmer,1958 (originally published in 1940); Goffman, 1992, (originally published in 1961); Gozzano, 1971, pp. 240-246; Liebling and Maruna (eds.), 2005, p. 3.

2 On the theory of labelling the offender, further consultation can be done on Larrauri, 1999, pp. 8 to 20 . 
relative and preventive and then move to absolute or retributive theories. Mixed theories will not here come under scrutiny, which for in our view are no more than a juxtaposition of absolute and relative doctrines. According to these, justification of life imprisonment can be a great deal severer, since it requires justification from an absolute and relative perspective, such as Roxin (1997) gives, or it may consist of a combination of absolute and relative fundamental criteria. Nor will we dwell on the negative theories of punishment: since they deny that the penalty has legitimacy, they clearly do not justify life imprisonment.

\subsection{Relative theories}

\section{a) General prevention}

As far as general prevention (positive or negative) is concerned, life imprisonment can be justified only if it is empirically demonstrated that it prevents crimes (Cuneo, 2017, p. 100). This line of thinking comes up against two practical issues: on the one hand, such compatibility seems difficult because experience shows that crimes punishable for long periods of time with severe penalties continue to be committed, making it problematic to reconcile any penalty with general prevention. And, then again, it is difficult to define whether it is the penalty that generates a preventive effect, or whether, most people prefer not to commit a crime not out of any dread of punishment, but out of other ethical considerations. While general prevention does not appear to encounter axiological impediments to justifying and defending life imprisonment, it does seem difficult to determine that this sanction does indeed lead to the anticipated outcome.

Already with Beccaria it was said that crime prevention is achieved more by the certainty of the penalty than by its severity. Therefore, if the Lombard Marquis is correct, the question of giving legitimacy to life imprisonment would appear to be complex, at least from the perspective of general prevention. ${ }^{3}$ On the same line of thought, according to Silvia Sanchez, "while increases in the severity of penalties have no proven preventive effects, those are visible when reinforcing the factors influencing greater certainty of the sanction (...) if the increase of certainty of criminal sanctions (and therefore, in general, the increase

3 The assertion that criminal law does not intimidate has been upheld by several authors. According to Muñoz Conde, "in any case it cannot be accepted [...] that criminal laws cooperate productively in increasing or decreasing criminality" in Muñoz Conde, 1999, p. 125; according to Bustos y Hormazábal, preventive - general effects cannot be empirically demonstrated, in Bustos and Hormazábal, 1997. 
of certainty that the penal system will function satisfactorily), means verifiable increases in the preventive effectiveness of the rules, it indicates that criminal law as a whole intimidates more than its absence would intimidate» (Silva Sánchez, 2010, pp. 252-253). ${ }^{4}$

The key issue of the empirical justification of life imprisonment lies in the fact that it has only been applied to crimes of high severity and it is precisely the perpetrators of these crimes who are usually difficult to intimidate; therefore, the intimidating threat will hardly produce the desired effects of this penalty. Paradoxically, it would be possible to conclude that life imprisonment would be justifiable, from a general prevention point of view, if drunken driving or a white-collar crime were punished with this penalty. On the other hand, it would appear difficult to justify it with respect to rape and murder.

Nor do we dare to go as far as to claim that this penalty would ensure the social peace sought after or desired by positive general prevention would indeed be achieved, although it could be argued, on citing specific earlier cases, that this does occur. In this respect, we do not know of any empirical studies that could prove this positive upshot of general positive prevention and we cannot imagine how they could be elaborated. To conclude, we believe that life imprisonment cannot be justified on the basis of negative general preventive criteria and we are unable to offer a categorical answer on its positive modality.

\section{b) Special prevention}

In principle, special negative prevention could justify life imprisonment, because the subject locked up in prison will not be able to perpetrate crimes against the free community (Cuneo, 2017, p. 104). However, many crimes are committed in prison, from robberies and thefts, to forgeries, illegal traffic of alcohol and drugs, rapes and homicides. Today, in addition,

4 Different studies have demonstrated that more important than the severity of the sanction is its likelihood. On the specific subject: Lieberman, 1993; Azrin, Holz and Hake, 1963; Lande, 1981, p.35; among others. Another important dissuasive factor is the postponement, in the sense that a sanction close to the perpetration of a crime can be more dissuasive than a more serious one if it is more immediate. On the subject: Solomon, Turner and Lessac, 1996. With regards to Solomon, Turner and Lessac's studies, we must be extremely cautious, since we do not think that the reactions of sanctioned animals can be compared with those of sanctioned people. It is difficult, if not impossible, that a dog understands the reasoning of a punishment for something it committed a week earlier. On the contrary, we believe that a human can understand the punishment inflicted months and even years after the commitment of a crime. 
multiple crimes are committed from inside the prisons towards the free community; for example, telephone scams, currency forgery, drug trafficking, etc. Moreover, organised crime groups, mafia and drug traffickers, usually recruit their soldiers in prison, who, once free, due to lack of opportunities, rapidly enter the frontlines of these organised crime groups. In those circumstances, it appears chimerical to affirm that the privation of liberty means that the inmate will not commit crimes. Prisons are a long way off from being a place where only a custodial sentence is served in which their prisoners live together without committing crimes, preparing for longedfor social reinsertion. Rather, on the contrary: levels of violence and the constant occurrence of crimes in the majority of prisons are far higher than in the free community. However, it is clear that, at least with respect to free society, the possibilities of committing crimes from prison are much lower than those of a free individual. Therefore, if this theory is capable of denying the dignity of those persons deprived of liberty, life imprisonment may well be justified for them.

According to special positive prevention, life imprisonment is justified only if we consider the existence of individuals whose re-socialisation is impossible, because, by separating the offender for life, it does not give him/her the opportunity to re-socialize. That is to say, this theory would justify life imprisonment only with respect to irredeemable criminals. That is to say in order for this theory, professing re-socialisation, to justify life punishment, it is necessary for it to creates the existence of inferior human beings that need to be separated from social coexistence.

\subsection{Retribution}

According to retribution, life imprisonment cannot be justified, and this is on account of two interrelated reasons. First of all, because if retribution, being as it is degrading, regards criminals as people responsible for their actions, it should still see them as such when condemning them and throughout the time they serve their sentence. That is to say, according to retribution, criminals are indeed people as they respond for their own actions and when responding for them, that is to say, when they are serving the sentence they continue to be people, therefore penalties dehumanising convicts are omitted. The second reason as to why we maintain that retribution cannot justify life imprisonment is because retribution at the time of the sanction targets the $I$, the subject's identity, which, over the course of time changes, meaning the individual may no longer be punished for a crime committed long ago. We will start by analysing the first reason, while the second issue, concerning the individual's change of identity over the course of time, is to be discussed towards the end or our argumentation. 
a) Retribution necessarily leads to a notion of an anthropologically-founded criminal law, a criminal law of people and for the people ${ }^{5}$, in which one cannot fail to see oneself in the convict as a fellow being. For this reason, life punishments are inadmissible, owing to their radical inhumanity, in that the concept of retribution itself envisages the person as an end, not as a means. This idea contrasts with both those who propose, justify or legitimise approaches that see the existence of human beings who are not persons as well as with a so-called criminal law of the enemy. ${ }^{6}$

This first limitation is based on a principle of humanity that concurs with every understood retribution. On the basis of security and through it, one comes to humanity, a community in its purest form, to cohabitation, which is not merely restricted to coexistence. The principle of humanity also implicates a sense of solidarity, individualism, which is not selfish, and leads to the realization of humanity both collectively and individuallyspeaking. It is not a humanity understood as one of fine sentiments, sentimentalism, tender-heartedness nor one speaking in weepy terms, but a humanity of Criminal Law drawn up objectively. This humanity, although its meaning is collective, culminates in an individual sense, because it conceives the human being as a person with its own individual dignity, holder of a personal and non-transferable destiny, with a capacity to dream and carry out their own actions with a series of implicit possibilities making that community, that coexistence, possible.

It is precisely this principle of humanity that makes Criminal Law meaningful. As such, Criminal Law according to this liberal conception, should be minimal, of ultima ratio, and should lead to a reductive, minimal meaning: when punishing it should apply the minimal affliction, only that which is indispensable. A liberal criminal law, humanised, that is applied to a community of free human beings, must necessarily be a reduced and fragmentary criminal law. An authoritarian criminal law, on the contrary, is not fragmentary. The least that can be done, by virtue of the principle of humanity, is to reduce penalties, decriminalise, depenalise, dejudicialise behaviour. We need to extract things from the Penal Law and foster models of conflict resolution. By virtue of the principle of humanity, punishments that treat criminals as non-people that exclude them, such as the death penalty or imprisonment,

5 The denomination we took from Rivacoba, 1999, pp. 57-62.

6 Accordinag to Zaffaroni every penal discourse that accepts or legitimises the existence of enemies not only carries an element of absolute state, but also implies a seed of genocide, and if no accident stops the course that it triggers, its final result is massacre (Zaffaroni, 2009, p. 25). 
which in more or less prolonged periods breaks with cohabitation and nullifies personality, should be ruled out. A prolonged imprisonment, beyond certain limits - e.g. 15 years - causes severe and irreversible harm to the personality. Sentences of twenty or more years are, in fact, perpetual, because, although one returns to freedom, one becomes annihilated.

Although no one refutes the principle of humanity outright, this is deformed by the different ways in which this is adopted by the various legal systems are adopted. Preventivist doctrines disagree with this principle, given they degrade humanity and the dignity of the human being, transforming it into a mere instrument for goals set by others. With retribution, on the contrary, the devaluation of punishment is however achieved without the convict being excluded from cohabitation.

Goethe's words should here be taken into account, in the sense that in a community where human beings are free and as ends in themselves, whether it is to punish or to be soft, people should be treated with humanity. And being an end in itself means being a person with dignity. Acknowledging dignity forms the basis for equality, assuming that with dignity, no one is more dignified than the next person, but we are all equally dignified. With dignity hierarchies are excluded. A criminal law that is not liberal is only a phenomenon of power, it is pure punitive power and not law.

With regards to the maximum limits that a custodial sentence must entail (necessary for a proper retribution), these cannot be such as to cause irretrievable physical and psychological degradation. If we conclude that a sentence of more than 15 years of privation of liberty has a dehumanising impact on the criminal, then the penalty cannot exceed aforesaid time.

According to Von Hirsch, who puts forward a theory of deserving applied in a benign form, prison should be limited to serious crimes (mainly violent crimes and the most serious white-collars crimes), and the duration of the limiting of freedom for those crime should be no more than 3 years- except for murder, where 5 years would be the normal limit- (Von Hirsch, 1998, p. 80). These limits are based, according to Von Hirsch, on psychological studies that account for the deterioration generated by the prison sentence (Von Hirsch, 1998). On the other hand, Kleinig, based not so much on a theory of deserving as on the idea of the humane and decent treatment of human beings, proposes as a maximum penalty of 25 years (Von Hirsch, 1998, p. 74).

b) Retribution targets the $I$, at the personal identity of the subject, which changes with time. Given what has previously been discussed, it seems pertinent to ask ourselves a further question on the personal identity of the $I$. 
Fortunately, criminal law nowadays does not usually discuss the validity of a principle called the personality of penalties, according to which the sentence must be imposed on the subject considered responsible for the crime, who is the one that has to bear it (Silva Sánchez, 2008, p. 662). ${ }^{7}$ This principle, together with the one on responsibility for one's own action, integrates the principle of guilt in a broad sense (Silva Sánchez, 2008, p. 662) according to which only the same individual may be punished that committed the crime and who has been found responsible after a trial. On the contrary, when the penalty falls onto a different subject than the one who committed the crime, the principle of culpability is infringed. The requirement of identity of the subject compares individual identity to physical identity. Apparently, what lies behind the requirement of personal identity and the principle of guilt is the idea of deserving, essential to any retribution. ${ }^{8}$ But what is personal identity?

To answer this question, at least two philosophical schools of thought should be analysed. On one side, the empiricists or reductionists, who based on the physical and psychic changes that the person undergoes over the course of time, deny the subject's personal identity in different moments. ${ }^{9}$ According to them, not being able to assert the existence of a personal identity, at the most we could speak of a «mere community of successive mental states, phases or personal stages" (Silva Sánchez, 2008, p. 666). In line with this thinking it would be appropriate to consider whether it is possible to hold criminally liable a subject in a time subsequent to that when the offence was committed (in the 2nd moment), seeing them in terms of the successor of that apparently same subject for a crime committed at a previous time (in the 1st moment). Since it seems difficult to argue that they should not be held accountable, the most pertinent question, in our opinion, would be whether or not we could reduce or annul this imputation on the basis of some change (time lapse or a traumatic event).

According to the other line of thinking, metaphysics, personal identity does indeed exist in the subject at different times. There is "a substantial personal

7 Apparently, the first to sense this principle would have been Dante Aligheri. At least that is according to Carrara, 1970, p. 647.

8 On the contrary preventist theories may well dispense with the notion of merit in order to achieve the desired preventive ends

9 Among the supporters of this position are Locke and Hume. According to the former. "who has forgotten their crime does not deserve punishment", in Silva Sánchez, 2008, pp. 666 y 680. This assertion is due to Locke's conception that rejects the criterion of corporal identity assuming that of consciousness based on memories. In Merkel, 1999, pp. 505-506. 
identity based on the permanent presence of corporal and spiritual components in the subject (...) (Silva Sánchez, 2008, p. 667). it is an essential permanent presence. As will be understood, according to this thesis neither time nor transcendent events would alter the individual essence. Therefore, there would be no problem in attributing responsibility for a past crime, even if several decades have passed, since it would be the same identical subject. Usually, for different legal-penal systems «personal identity is imputed» (Silva Sánchez, 2008 , p. 670). However, for practical reasons and those of justice, it seems necessary to limit such a normativist concept. Criminal doctrine overlooks the fact that the subject does change and assumes that the subject is always the same (so it is imputed); the time limits that are established in criminal law are related to practical reasons rather than to the supposed change of the $I$.

According to Merkel, the tacit demands of criminal prosecutions imply the assumption that, over the course of time, the subjects of significant criminal proceedings remain identical to themselves as persons (Merkel, 1999, p. 502). However, this author is of the opinion that, in certain situations, this statement is false or implausible. To address the problem of identity in time - which, according to Merkel, has not been sufficiently developed by criminal science - we should recollect the Greek myth, told by Plutarch, of Theseus's ship, who on his return from Crete had the vessel's broken boards removed one by one, replacing them with new ones, to the point where he no longer preserved any of the originals. From this, the question arises whether it would still be the same ship after all the boards have been replaced. Merkel then adds a variant to the example: a sailor then collects all the parts that have been discarded to be replaced by new ones and builds a ship exactly the same as Theseus's. Which one would then be the original ship? For Merkel there could be three possible answers: the first one, the second or neither, since logically they could not be both at the same time. At the heart of the question lies the dilemma of whether, once the parts that make up a whole have changed, the identity is still there. If we transfer this example to human beings, it may be argued that, at least on a physical-biological level, people do not maintain a single cell throughout their lives, as they are all constantly undergoing renewal. Are we still then the same person after a certain period of time or after a certain amount of changes? ${ }^{10}$

10 Merkel illustrates this by referring to two science fiction cases. Firstly, he raises the problem of teleportation. A machine stores the information of all our cells in point A and reproduces this in point $B$. Is the person in point $B$ the same that was in point $A$ ? The second example answers a real life case, led by the BGH in 1983 under the name SiriusFall. A man convinces a young woman that she has been chosen to transmute into a superior being once she leaves her present body. If the change occurs, will the young woman be the same person as before? Merkel, 1999, pp. 53-55. 
Furthermore, what about the changes we experience at a psychological level? Do they also change our identify of the I? On this subject, Merkel analyses cases of Alzheimer and total loss of memory. Is an individual still the same person after complete loss of autonomy or any connection with his/her past? And, linking this to our own investigation, can we sentence someone who has no memory of their crime? For us, this question is also important with regards to when the sentence is implemented. If the offender loses their memory, can they continue to serve the sentence for something that is not recalled? Can we affirm that we continue inflict retribution on someone who does not know why he/she is serving a sentence? ${ }^{11}$

If we are to understand that with time just deserts, the verdict meting out blame and the need for punishment diminish, then we should be asking ourselves when or in what circumstances the culpability of the subject in the past vanishes to such an extent that the punishment does not seem to be fair. ${ }^{12}$ Both metaphysical and empirical theories, as they work on totally abstract levels, do not appear to satisfy the legal-criminal issues of the real world, such as the affliction of the prisoner suffering from loneliness in their cell. However, we may ascribe ourselves to an eclectic theory, understanding that there would be no problem to impute to a subject his previous actions with certain temporal or circumstantial limits; ${ }^{13}$ that is to say, we understand, from retribution, that the subject must answer for their past actions, but not indefinitely and perpetually.

The point is to think about guilt in a dynamic way, bearing in mind that the passing of time ensures the culpability of the subject is not same culpability attributed to him at the moment of sentencing and for which he/she was convicted in order to compensate for the deed that constituted a crime. This is a structural limitation that is understood to be meaningless if someone is sanctioned for the rest of his/her life or for excessively long periods.

11 Merkel refers to a case of a man who, after a bike accident, suffered total memory loss and continued pedalling without a fixed destination, drinking from open toilets, sleeping on the open air and not eating. After a week of incessant walking he wondered what he was doing and did not know how to answer himself. Merkel asked himself the question: if this man would have committed a crime before the accident, could we condemn him for it, even though he wouldn't recall it? Merkel, 1999, p. 509.

12 It could be argued that it is the action/fact that with time deserves less reproach. However, we will not go into this subject in order to focus entirely on the reduction of the subject's guilt due to the course of time or the occurrence of special circumstances.

13 For our object of study, we will focus on the time limits. Circumstantials could be, for example, a context of war, a serious economic crisis or a natural catastrophe. These circumstances could awaken in the subject primitive instincts prevailing those of selfpreservation. 
Even if we are aware that the individual changes with time, we are not sure whether it is possible to say that at any moment this person is no longer the same who committed the crime. Something leads us to think that, after 20 years of the passing of sentence, he/she is no longer the same person who committed the crime. Clearly neither North American legislation nor several U.S. courts concur with our thesis, which repeatedly sentence minors between the ages of thirteen and seventeen to life imprisonment without the possibility of parole.

A study undertaken by Amnesty International and Human Rights Watch, published in 2005, shows that there are, in the United States, at last 2,225 people serving life imprisonment without parole for crimes committed when under the age of 18, for most of whom it was their first offense. $16 \%$ of those convicted would have committed their crime when aged between thirteen and fifteen (Human Right Watch, 2005). The dramatic situation outlined in Amnesty International's and Human Rights Watch's report seems difficult to defend from a preventive point of view, although in relation to what we are dealing with now, this situation is unacceptable for a retributionist standpoint and not only because of the evident inhumanity of these punishments, since if the sentence is based on retribution, we must understand we are continuing to inflict punishment for the crime throughout the entire serving of the prison sentence. This forms the basis for our idea that retribution would then, at some point, be an undeserved because culpability, harnessed to personal identity, has diminished over time and with the change of identity of the subject, reaching a time to be so minimal as to no longer be able to justify the penalty.

After twenty or forty years an individual's core identity may still be there, but this core identity does not appear sufficient to justify the logic of responsibility, the logic of deservedness, the logic of retribution, because there would not be a sufficiently strong identity linking the same person who committed the crime with that serving the sentence at a much later stage in time. If we affirm that the subject changes, as his personal identity keeps on changing, there will come a time when it is no longer possible to continue compensating culpability because the person has come to have a different identity.

Our stated idea here professes that this subject cannot be held responsible after a long period of time has elapsed, because they would no longer be the same. Life imprisonment or a long sentence would involve an excess of punishment that could not be compensated by culpability, because culpability, understood as that part of oneself, determined by one's own will, by one's I that at a given moment has decided to commit an act of delinquency, is no 
longer the same. Although our theory appears to be a mere intuition, as it is impossible for us to empirically know if and when a person happens to have a different identity, we may attempt to make our assumptions of a scientific nature by linking them to studies on the phases of biological and psychological development. ${ }^{14}$

Erik Erikson, a German psychoanalyst (1902-1994), created in the United States a personality development theory in which he describes eight stages of the psychosocial development of the human being (Erikson, 1980, p. 80). According to Erikson, a psychologically sane person should go through each one of those phases and suffer what is characteristic of each stage as well as enjoy its benefits.

The first four stages relate to crises and conflicts in the development of life up to the age of thirteen. These are: 1 . - Trust versus Mistrust, a stage that occurs from birth to eighteen months of age approximately; 2. - Autonomy versus Shame and Doubt, a stage that occurs from eighteen months to three years; 3 - Initiative versus Guilt, a stage that occurs from three to five years old; and 4. Industry versus Inferiority, a stage that occurs from five years to thirteen years old approximately.

The last four phases are those that matter the most to us in order to understand a limitation of liability of a legal-criminal nature, considering that before the age of thirteen it makes no sense to attribute any type of criminal liability. This could respond to the assertion that until adolescence, the individual cannot develop the requirements of physiological development, mental maturation and social responsibility to experience and go through the identity crisis (Erikson, 1980, p. 78). Let us look at the phases that-include life from adolescence to old age.

The fifth phase or Adolescence is characterised by the existence of a conflict of Identify Versus Confusion of Identity. It would cover the period the goes between thirteen and twenty years old. During this phase the young person seeks to define their own identity, it is a way of life between childhood and adulthood. Thus, in the last years of schooling, young people, harassed by the physiological revolution of their genital maturation and the uncertainty of their adult roles, seem very busy with capricious attempts to establish an adolescent subculture through what looks like a final identity (Erikson,

14 Criminal law must listen to science to limit its effects. The inimputability of children or the insane responds to conceptions that come from the world of explanatory causal disciplines. 
1980, p. 110). The sixth phase, the young adult, lives a conflict of intimacy versus isolation. This would cover the period that goes between twenty-one years up to forty years of age approximately and it is characterised by greater confidence, as it seems that this young adult would no longer need, as before, to prove something to themselves (Erikson, 1980, p. 111). The seventh phase, of adulthood, is characterised by a conflict of generativity versus stagnation, and would stretch from the forties to the sixties. This stage is usually related to parenting and is characterised by a constant concern for the future (of children, of future generations, etc.).

Lastly, in the eighth stage, of senescence or maturity, a conflict of integrity versus despair. This phase would cover the period from the age of sixty onwards, and is characterised by physical deterioration, the presence of disease, muscle weakening and a certain concern for one's own death or the death of peers. If philosophically we can justify the idea that the subject changes with time, that this affects culpability and furthermore that psychosocially these phases exist and have been analysed and studied by psychology, then it seems that what was only our intuition has a scientific basis enabling us to limit the sentence given as retribution, limit that would be around, according to the studies of Erikson, 20 years or less, that is to say, the duration of each stage (Erikson, 1980). ${ }^{15}$ This arises from the need for the individual to be able to live in freedom at each stage in order to aspire to full development.

From the retribution perspective it seems coherent that the evil of punishment is prolonged only in one of the four stages: that the crime committed at one stage of life be punished at the same stage as when the crime was committed. Exceptionally, if the crime was committed at the end of one of the phases, at nineteen for example, the sentence could pass to the next stage taking its age-frame as its point of reference. However, it would appear prudent to limit the sentence and in no case to exceed half of the next stage, thus leaving half of this cycle free for the subject to develop during this new phase. In this way, the principle of personality of the penalties will be respected, avoiding that the punishment is applied to a person who may have undergone radical changes in his or her personality.

15 A distorting factor that we must consider, with regard to sentences the deprive liberty, would be found in the psychological and physiological effects produced by confinement in the convicted person. Reclusion and routine mutate the perception of the time, causing that the condemned perceives that this one passes more slowly, which, we believe, affects and disfigures the phases or epochs that are natural to the man (Liebling and Maruna, 2005). 


\section{CONCLUSIONS}

Relative theories, which defend preventive functions rather than the ends, prefer empirical arguments (Rivacoba, 1993). Therefore, it does not seem to us that these approaches can be theories about the goal of the penalty, since they have a connotation of worth that cannot be found in observations of a purely utilitarian nature. That is why it is not feasible for us to offer a categorical answer as to whether or not prevention can justify life imprisonment, since this justification will depend on factual data through which it will be possible to verify whether or not the envisaged goals have been achieved (Alcácer, 1998). Thus, for example, life imprisonment may be justified on the basis of negative general prevention, if proven it intimidates; or on the basis of negative special prevention, if it is demonstrated that it does indeed separate the criminal from the community, etc.

On the other hand, sustaining retribution moves in the realm of values is not the same as saying that it should disdainfully disregard reality data, since the nature and abstract measure of punishment depend on historical considerations. Retribution, entirely detached from the real impact of punishment on the prisoner and on society, degenerates into the retribution envisaged by Hegelian idealism, in the sense that it would mete out punishment because punishment has to be meted out, period. In line with this concept of retribution, heeding the social reality and especially the impact punishment has on the criminal, any possible justification of life imprisonment and very long sentences is to be discarded by us, on account of the two reasons expounded above. We would now like, on concluding these reflections, to outline our own proposal for time limits on custodial sentences. First of all, we believe that we should reserve the prison sentence only for crimes of special gravity, either against individual property (murder, rape and other), or against collective legal property whose criminal offense seriously affects a multitude of people (mainly crimes against public order and economic order). And for crimes of low or medium gravity, we propose the establishment of penalties other than imprisonment, which are not presented to the law as alternative penalties to imprisonment, rather as the immediate and sole penalty for those crimes. With regards to custodial sentences, and in view of the irreversible harm caused to the convicted person by a prison sentence of more than fifteen years, we propose that this should be the maximum limit of the custodial sentence.

In relation to Erikson's studies, cited in the second part, and on the understanding that of the four stages which are relevant to the criminal charge of responsibility, there is one of a shorter temporal duration - specifically, adolescence or fifth stage, which Erikson defines as a period ranging from thirteen to twenty-one years - we propose an eight-year limit as the maximum 
custodial sentence for crimes perpetrated by adolescents, meaning by people who, at the time of committing the crime, were between eighteen ${ }^{16}$ and twentyone years old.

\section{BIBLIOGRAPHY}

Alcácer Guirao, Rafael, "Los fines del Derecho penal. Una aproximación desde la filosofía política", Anuario de Derecho penal y Ciencias penales (available: http:/ /vlex.com/vid/fines-aproximacion-filosofia-politica-383186, 1998.

Azrin, N., W. C. Holz y D. F. Hake, "Fixed Ratio Punishment”, Experimental Analysis of Behavior, 6, available: http://www.ncbi.nlm.nih.gov/pmc/articles/ PMC1404287/pdf/jeabehav00187-0003.pdf., 1963, latest revision 15th July 2020.

Bustos, Juan y Hormazábal, Hernán, Lecciones de Derecho penal (vol. I), Madrid, Editorial Trotta, 1997.

Carrara, Francesco, “Dante criminalista”, Opuscoli di Diritto criminale, Lucca, 1970.

Clemmer, Donald, The Prision Community, New York, Holt, Rinehart and Winston, 1958.

Crofts, N., Stewart, T., Hearne, P., Ping, X.Z., Breschkin, A.M. y Locarni, S.A., “Spread of bloodborne viruses among Australian prison entrants", British Medical Journal, 310 (6975), 1995.

CUNEO, Silvio, Encarcelamiento masivo, Buenos Aires, Didot, 2017.

Erikson, Erik, Identidad, juventud y crisis, Trad: Guéra, Alfredo, Madrid, Taurus Ediciones S. A., 1980.

Goffman, Erving, Internados. Ensayos sobre la situación social de los enfermos mentales, Trad: Oyuela, María, Buenos Aires, Talleres Gráficos Color Efe, 1992.

Gozzano, Mario, Compendio di psichiatria clinica e criminológica, Turin, Rosenberg \& Sellier, 1971.

HUMAN RIGHT WATCH, “United States: Thousands of Children Sentenced to Life without Parole", Available in the web site: https://www.hrw.org/news/2005/

16 This considering that under the age of sixteen there should be no criminal charges and also, between the ages of sixteen and eighteen, a special criminal law regime with milder treatment for minors. 
10/11/united-states-thousands-children-sentenced-life-without-parole\# latest revision 15th March 2020.

Jakobs, Günther, Derecho penal del enemigo, Trad: Cancio Meliá, Manuel, Madrid, Ed. Civitas, 2003.

Jakobs, Günther, “Individuo y persona. Sobre la imputación jurídico-penal y los resultados de la moderna investigación neurológica", Teoría funcional de la pena y de la culpabilidad, Trads: Cancio Meliá, Manuel y Feijoo, Bernardo, Madrid, Civitas, 2008.

Lande, S., "An Irresponsive Time Analysis of Variable-Ratio Punishment", Journal of Experimental Analysis of Behavior, 35, 1981.

Larrauri, Elena, “Para qué sirve la criminología?”, Cuadernos de Derecho Judicial CJPG, Madrid, Política Criminal, 1999.

Lieberman, David, Learning, Behavior, and Cognition, Belmont, Wadsworth Publishing, 1993.

Liebling, Alison and Maruna, Shadd (eds.), The effects of imprisonment, Londres, Willan Publishing, 2005.

Loewenstein, George, “Out of Control: Visceral Influences of Behavior”, en Organizational Behavior and Human Decision Processes, 65 Carnegie Mellon University, 1996.

Merkel, Reinhardt, "Personale Identität und die Grenzen strafrechtlicher Zurechnung", Juristen Zeitung (10), 1999.

Molina Fernández, Fernando, “¿Culpabilidad sin libertad?”, Teoría funcional de la pena y de la culpabilidad, Madrid, Civitas, 2008.

Muñoz Conde, Francisco, Derecho penal y control social, Santa Fe de Bogotá, Editorial Temis S. A., 1999.

Muñoz Conde, Francisco, "Apéndice", La reforma penal nacional-socialista", Buenos Aires, Ediar, 2009.

Rivacoba, Manuel, Función y aplicación de la pena, Buenos Aires, Editorial Depalma, 1993.

Rivacoba, Manuel, "Introducción al estudio de los principios cardinales de Derecho penal", Direito e Ciudadania (6), Praia, Cabo Verde, Ciudadanía, 1999.

Roxin, Claus, Derecho penal parte general. Tomo I. Fundamentos. La estructura de la teoría del delito, Trads: Luzón Peña, Diego, Díaz y García Conlledo, Miguel, Vicente Remesal, Javier, Madrid, Civitas, 1997. 
Silva Sánchez, Jesús María, "Del Derecho abstracto al Derecho real”, Indret (4), 2006 (http://www.indret.com/pdf/377_es.pdf).

Silva Sánchez, Jesúa María, "Identidad en el tiempo y responsabilidad penal. El juicio jurisdiccional de imputación de responsabilidad y la identidad entre agente y acusado", Estudios penales en homenaje a Enrique Gimbernat (t. II), Madrid, Edisofer, 2008.

Silva Sánchez, Jesús María, Aproximación al Derecho penal contemporáneo, $2^{\text {nd }}$ amplified and updated edition, Buenos Aires, B de F, 2010.

Solomon, R., Turner, L. H. y Lessac, M. S., "Some Effects of Delay of Punishment on Resistence to Temptation in Dos", en Journal of Personality and Social Psychology, 8, 1968.

Von Hirsch, Andrew, Censurar y Castigar, Trad: Larrauri, Elena, Madrid, Trotta, 1998.

Zaffaroni, Rául, El enemigo en el Derecho penal, Ediar, Buenos Aires, 2007.

Zaffaroni, Raúl, “Introducción al libro: Grispigni, Filippo y Mezger, Edmund, La reforma penal nacional-socialista", Ediar, Buenos Aires, 2009. 
